\title{
IMPROVEMENT STRATEGY OF EMPLOYEE PERFORMANCE PT. PERKEBUNAN NUSANTARA V
}

\author{
Hendrasyah Putra \\ School of business, Bogor Agricultural University \\ Email: hsyah2579@gmail.com \\ Syamsul Maarif \\ School of business, Bogor Agricultural University \\ Email: syamsul4958@gmail.com
}

Received: December 2018; Accepted: January 2019; Available online: January 2019

\begin{abstract}
PT. Perkebunan Nusantara V is one of the companies engaged in oil palm plantations. During the 2011-2017 period PTPN V carried out the recruitment and selection process with a span of 2 years. New employees from the results of recruitment, selection and placement are required to always improve performance. The purpose of this study is to determine the effect of recruitment on performance, the effect of selection on performance, the effect of placement on performance, the effect of recruitment on selection, and the influence of selection on placement, as well as strategies to improve employee performance in PTPN V. This study uses Structural Equation Model Partial Least Squares (PLS-PLS) and the Analytic Hierarchy Process (AHP) to test the hypothesis. The sample of this study is 90 employees. The results of this study show that recruitment has no effect on performance, selection has a significant effect on employee performance, placement has a significant effect on employee performance, recruitment has a significant effect on selection and selection has a significant effect on placement. Then the results of the formulation of the right strategy is to improve employee welfare, development of performance and competency based HRM, improve the recruitment system according to needs and improve performance monitoring and evaluation.
\end{abstract}

Keywords: Recruitment, Selection, Placement, Employee Performance, Performance improvement

\section{Abstrak}

PT. Perkebunan Nusantara $V$ adalah salah satu perusahaan yang bergerak di perkebunan kelapa sawit dan karet. Selama periode 2011-2017 PTPN V melakukan proses rekrutmen dan seleksi dengan rentang waktu 2 tahun. Karyawan baru dari hasil rekrutmen, seleksi dan penempatan dituntut untuk selalu meningkatkan kinerja. Tujuan dari penelitian ini adalah untuk mengetahui pengaruh rekrutmen terhadap kinerja, pengaruh seleksi terhadap kinerja, pengaruh penempatan terhadap kinerja, pengaruh rekrutmen terhadap seleksi, dan pengaruh seleksi terhadap penempatan, serta strategi untuk meningkatkan kinerja karyawan di PTPN V. Metode yang digunakan dalam penelitian ini adalah metode Structural Equation Model Partial Least Squares (PLS-PLS) dan metode Analytic Hierarchy Process (AHP). Sampel penelitian ini adalah 90 karyawan. Hasil penelitian ini adalah bahwa rekrutmen tidak berpengaruh terhadap kinerja, seleksi berpengaruh signifikan terhadap kinerja karyawan, penempatan berpengaruh signifikan terhadap kinerja karyawan, rekrutmen berpengaruh signifikan terhadap seleksi, dan seleksi berpengaruh signifikan terhadap penempatan. Kemudian hasil perumusan strategi yang tepat adalah meningkatkan kesejahteraan karyawan, pengembangan kinerja dan kompetensi berbasis SDM, meningkatkan sistem rekrutmen sesuai kebutuhan dan meningkatkan pemantauan dan evaluasi kinerja

Kata Kunci: kinerja, penempatan, peningkatan kinerja, rekrutmen, seleksi.

How to Cite: Putra, H., \& Maarif, S. (2019). Improvement Strategy of Employee Performance PT. Perkebunan Nusantara V. Media Ekonomi dan Manajemen, 34(1), 85-101. 


\section{INTRODUCTION}

For companies engaged in the plantation sector, facing fierce competition in a business activity really needs an effort to anticipate these conditions as early as possible. One effort is to improve the quality of human resources. There are many aspects that must be done to obtain professional human resources; i.e. through recruitment, selection and placement of prospective employees (Mangkunegara, 2011).

PT Perkebunan Nusantara V (PTPN $\mathrm{V})$ is one of the companies engaged in oil palm plantations that has a vision of "becoming a sustainable and environmentally integrated agribusiness company" and the mission of "efficiently managing palm oil and rubber agroindustry with partners in the interests of stakeholders". It applies the principles of good corporate governance, criteria for sustainable palm oil, the application of industry standards and environmental sustainability to produce products that are acceptable by customers. It also creates competitive advantage in the field of human resources based on best practices and the latest management system to improve the company's core competencies" (PTPN V 2016). PTPN V requires qualified human resources who are able to make the company better in achieving organizational goals.

The number of PTPN V employees in 2016 was 12,485 people consisting of 509 leader employees, 11,696 implementer employees and 280 garden security officers, temporary employees, duty-free employees and trainees. (PTPN V 2016). In this study, the researchers are more interested in HR procurement for leader employees. This is because the leader employee is the leader of the smallest unit that is responsible for directing subordinates according to the goals of the company or experts who are responsible to give consideration and advice to leaders in accordance with their expertise.

Due to the importance of human resource planning that is needed by the company, the recruitment, selection and placement strategies of prospective workers are very necessary. The recruitment, selection and placement activities play a very important role for the success of the company, because this activity determines the company's ability to survive, adapt and develop itself in the middle of intense competition (Kristanu, 2013).

The phenomenon of depreciation in number of leader employees that occurred at PTPN V was caused by the retirement period, death, and/or dismissal from the company for committing violations of prescribed disciplinary rules. Therefore, it requires other employees to replace the position. During the 2011-2017 period, PTPN V carried out a recruitment and selection process with a span of 2 years due to the depreciation in number of the leader employees. This is carried out to make the employees evenly distributed so that the strength of its human resources is more balanced.

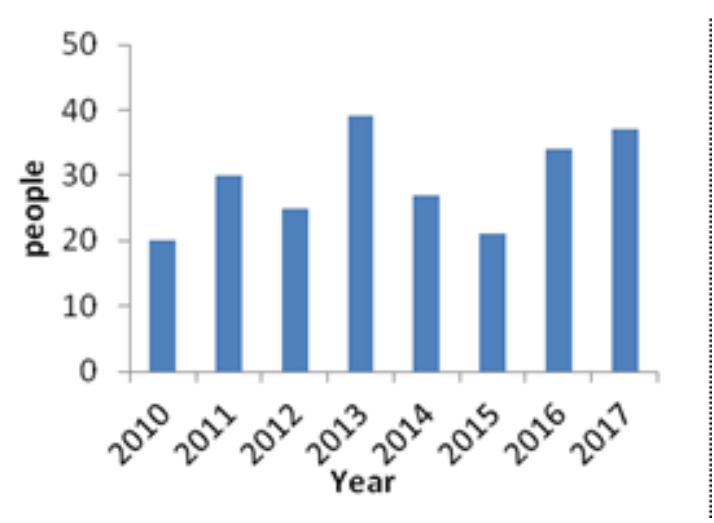

Figure 1. Employee Data of PT. Perkebunan Nusantara V who retired, died, laid off and resigned.

Source : PT. Perkebunan Nusantara V (2017)

The recruitment and selection system in PTPN V are not only the recruitment of prospective applicants from outside the company (external). However, to improve the effectiveness of the company, PTPN V also recruits internal company employees 
whose aim is to increase the morale of the existing workforce, maintain loyalty, motivate employees and reward employee achievements.

Table 1. PTPN V employee recruitment data

\begin{tabular}{cccc}
\hline \multirow{2}{*}{ Year } & \multicolumn{2}{c}{ Recruitment } & Total \\
\cline { 2 - 3 } & Internal & External & (people) \\
\hline 2011 & 37 & 29 & 66 \\
2013 & 33 & 7 & 40 \\
2015 & 14 & 60 & 74 \\
2017 & 46 & - & 46 \\
\hline
\end{tabular}

Source: PT. Perkebunan Nusantara V (2017)

Table 1 shows the recruitment carried out by PTPN V from 2011-2017. In 2011, it recruited 66 people consisting of 37 people from internal company or employees who had worked for the company but were promoted to become leader employees; whereas, 29 other people were recruited from outside the company or from the public. In 2013, there were 37 internal employees and 7 external employees. In 2015, there were 14 internal employees and 60 external employees. In 2017 , employees were recruited only from internal companies. With the addition of new leadership employees from the results of recruitment, selection and placement are required to always improve performance so that the company can continue to develop itself.

Previous research, conducted by Aziz (2017) regarding the effect of recruitment and selection on employee performance using the SEM analysis method, found that recruitment has an effect on selection, selection has an effect on performance, and recruitment directly has an effect on performance. Sarinah et al. (2016) also conducted a study on the effect of recruitment, selection and placement using path analysis method which found that the recruitment and selection significantly has an effect on placement and the placement of employees also has a significant effect on employee performance. Furthermore, Kanu (2015) examined the impact of recruitment and selection on performance using qualitative and quantitative methods with the analysis of Pearson correlation coefficient which found a significant relationship between recruitment, selection and performance.

Based on the identification of the above problems, the formulation of the problems that are the focus of this research include:

1. Whether the recruitment influences on the performance of PTPN V employees?

2. Whether the selection influences on the performance of PTPN V employees?

3. Whether the placement influences on the performance of PTPN V employees?

4. Whether the recruitment influences on the selection of PTPN V employees?

5. Whether the selection influences on the placement of PTPN V employees?

6. What are the strategies to improve the performance of employees of PT Perkebunan Nusantara V?

Based on the description of the background and the formulation of the problems, the objectives of this study are as follows:

1. Analyzing the effect of recruitment on the performance of PTPN V employees.

2. Analyzing the effect of selection on the performance of PTPN V employees.

3. Analyzing effect of placement on the performance of PTPN V employees.

4. Analyzing the effect of recruitment on the selection of PTPN V employees.

5. Analyzing the effect of selection on the placement of PTPN V employees.

6. Formulating strategies to improve employee performance that are appropriate to be applied at PTPN V.

\section{LITERATURE REVIEW}

\section{Recruitment}

The company's recruitment program and its effectiveness are the main roles in the strategic decision-making process, because this is a major investment for a company (Sangeetha, 2010). Recruitment, according to Noe et al. (2010), is all activities carried out by organizations that 
aim to identify and find employees needed by the organization. This process aims to stimulate potential employees who are in accordance with the needs of the company to apply. Furthermore, they will be selected to find the most appropriate employees who will fill the existing jobs. Organizations must prepare job specifications for these vacant positions and then strictly follow them during employee recruitment and selection. (Kepha et al., 2014). Besides, the recruitment is an effort to select the composition of human resources to be more balanced.

To implement a successful recruitment strategy, the organization or company can use two or more styles from various categories of recruitment methods such as job advertisements, referrals by existing employees, recruitment from universities, agents or expert involvement, job boards, company websites, social media and others (Sinha and Thaly, 2013). An effective recruitment process will produce an organization that has a competitive advantage in the market, increases returns, and achieves economies of scale (Palaniapan and Arasu, 2017). The process of implementing successful recruitment will help the company to achieve its objectives which include increasing the stability of human resources, providing sufficient and best applicants to fill existing vacancies at low costs and increasing the effectiveness of the selection process (Azzam and Jarajat, 2014).

According to Mathis and Jackson (2006), indicators of the recruitment process variables include:

1. Basic source of employee recruitment It must be guided by the specifications of the work that has been determined to occupy the position.

2. Employee source

a. Internal source

Decide employees who meet the standards of the vacant position. b. External source

Employees who fill vacant positions are recruited from sources of labor outside the company.

3. Employee recruitment methods

a. Closed method

Recruitment is only informed to employees or certain people.

b. Open method

Recruitment is widely informed by advertising and sharing it to the public

\section{Selection}

Employee selection according to Noe et al. (2010), is to decide who will be accepted or not accepted as an employee of the company. According to Mathis and Jackson (2006), selection is an organizational process in selecting people to fill vacant positions needed by the organization. An organization will not succeed if there are no potential and qualified employees.

The selection process is an important part of the entire human resource process. Through this process, it will obtain a number of potential employees and those who meet the requirements which depends on the thoroughness and carefulness of the company in conducting the selection process. And this selection process is a part that cannot be separated from the recruitment process. The goal of selection practice is to get the right employees for the right position, build and maintain the reputation of employers in the market and ensure cost-effectiveness in the selection process (Gamage, 2014).

The selection procedure for obtaining employees with the potential for the right placement requires careful and efficiencybased determination. Selection criteria according to Simamora (2004) in general can be summarized in several categories, namely: a. education, b. reference, c. experience, d. Medical check, e. written test, and f. interview test.

From the explanation about the selection, the selection carried out according to the procedure and correctly 
will get the qualifications of human resources needed by the organization or company. By implementing the correct procedure, it will have a positive impact on the organization; that is, the ease in determining the qualifications of applicants who have passed the selection. Meanwhile, the advantage for job applicants is that they are not suspicious of the organization if applicants fail in the selection process feel satisfied. They might have selfintrospection that they have not been able to meet the standards set by the organization and company (Nuryanta, 2008).

\section{Placement}

One function of human resource management is to manage placement of employees. According to Siagian (2003), in modern HR management theory, placement does not only apply to employees who have just entered the company, but also apply to old employees who experience duties and transfers. It means that the actual placement of employees consists of two ways: new employees from outside the company and assignments in new places for old employees which also called internal placements.

According to Pratama (2017), the employee placement must be considered carefully and placed in accordance with the educational background and experience and in accordance with the conscience of employees with the procedures in the company. According to Suwatno (2003), placement of employees should consider the following matters: 1. Education and training, 2. Job knowledge, 3. Job skill, 4. Work experience.

\section{Performance}

The measure of the performance of an organization or company is to what extent the vision, mission and objectives of the organization or company can be achieved, the process or effort to achieve organizational goals is now better known as performance management. According to Mathis and Jackson (2006), a performance management system is an attempt to identify, encourage, measure, evaluate, improve and reward employee performance. Performance has broader definition and meaning. It is not only the result of work, but how the process of a work takes place.

According to Adebola (2017), performance is a series of work actions that integrate skills and knowledge to produce valuable results. There are six indicators to measure individual employee performance (Robbins, 2006) which include: 1. quality, 2. quantity, 3. time accuracy, 4. effectiveness, and 5. independence.

\section{Conceptual Framework}

The research starts with analyzing recruitment, selection and placement of employee performance based on the opinions of respondents. Furthermore, the measurement of the effect of recruitment, selection and placement on employee performance is carried out. Measurement of the effect is conducted using Structural Equation Modeling (SEM). Moreover, it formulates a strategy formulation to improve employee performance using AHP. The use of AHP will identify clearly the problem of PTPN V's performance improvement strategy. The results of the analysis form the basis of recommendations for PTPN $\mathrm{V}$ relating to employee performance. This framework can be seen in the following Figure 2. 


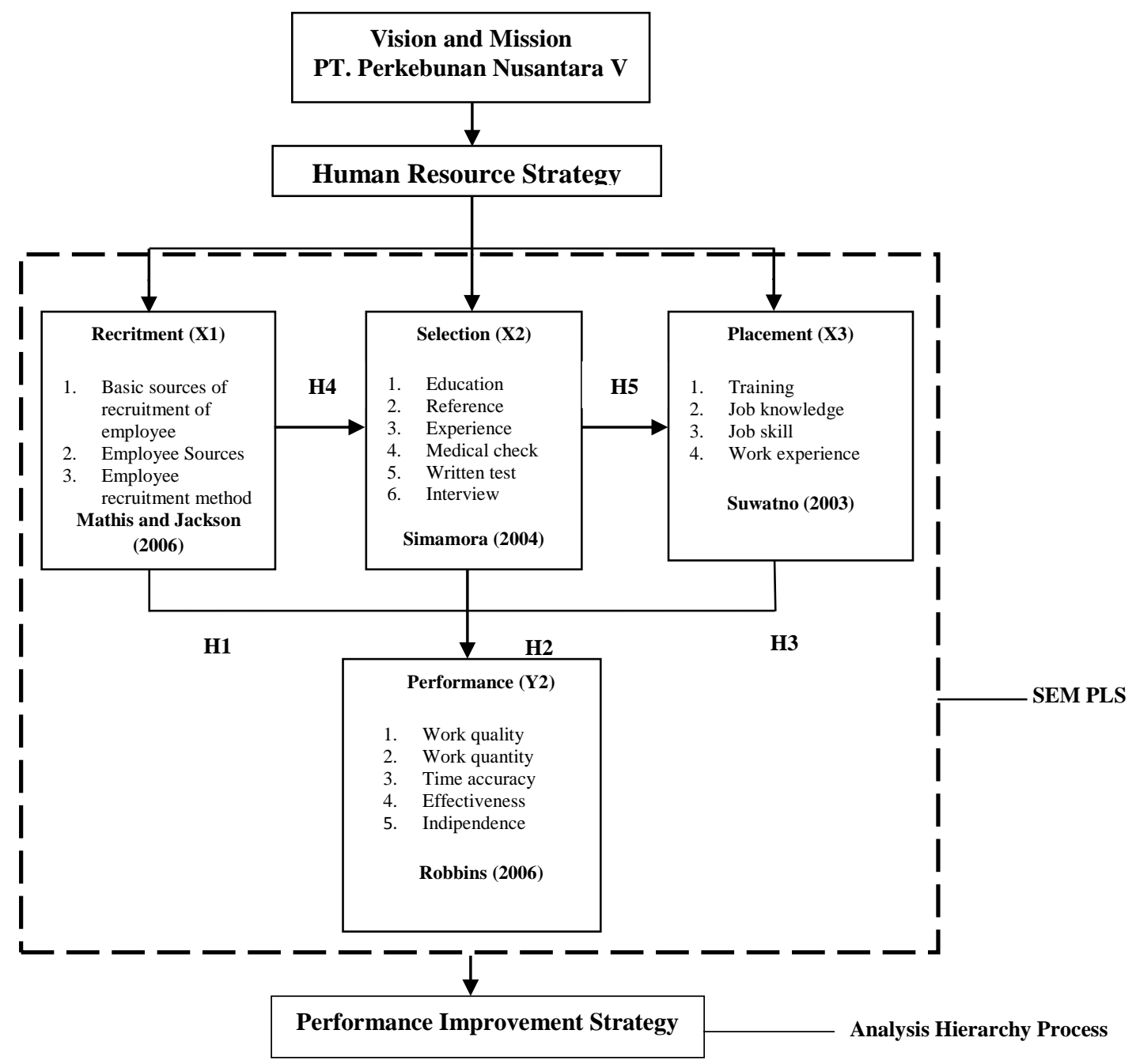

Figure 2. Conceptual Framework

Based on the conceptual framework, the hypotheses to be tested in this study are:

\section{The Effect of Recruitment on Employee Performance}

Recruitment is important in procuring prospective workers. The recruitment is intended to obtain employees who are qualified and able to carry out and realize the company's goals. Failure in the implementation of recruitment will affect employee performance, which in turn becomes a barrier to achieving company goals. Previous research that supports that recruitment has a positive effect on performance is a research conducted by Aziz (2017). Thus, H1 in this research is that recruitment has a positive effect on performance.

\section{The Effect of Selection on Employee Performance}

Employee selection according to Noe et al. (2010) is deciding who will be accepted or not accepted to become an employee of a company. The selection process in a company will determine whether or not the employee is appropriate to fill the vacant position. Therefore, a good selection process will obtain potential workers that will greatly affect the performance and goals of the company. Previous research supporting this finding is the research conducted by Tarjiwo (2018) and Kanu (2015). Thus, H2 in this research is that selection has a positive effect on employee performance. 


\section{The Effect of Placement on Employee Performance}

Placement, according to Hariandja (2006), is the process of filling in a position or reassigning a new or different position. A good placement is to put the right people in the right position. Placement can affect employee performance because good and right placement will foster employee enthusiasm in work. Previous research supporting this finding is research conducted by Pratama (2017) and Wibowo (2018). Thus, H3 in this research is that placement has a positive effect on employee performance.

\section{The Effect of Recruitment on Employee Selection}

Recruitment is the process of collecting applicants to the vacant positions. The recruitment process relates to the process of human resource planning and other HR management activities, especially the selection process, because the success of recruitment will affect the success of the selection. The use of a good selection procedure will affect the success of the recruitment process. Previous research that supports this finding is the research conducted by Yullyanti (2009). Thus, H4 in this research is that recruitment has a positive effect on selection.

\section{The Effect of Selection on Employee Placement}

Employee placement is a follow-up of the selection process. The results of the selection process will obtain employees who are in accordance with the position needed by the company. The selected employees will be satisfied if they are placed in a position that is in accordance with their abilities. Previous research supporting this finding is research conducted by Dewi and Darma (2017) and Rajaguguk (2014). Thus, H5 in this research is that selection has a positive effect on placement.

\section{METHODS OF RESEARCH}

The research was conducted at the Head Office of PTPN V Jalan Rambutan No. 43 Pekanbaru Riau and in PTPN V units, gardens and districts in Riau. The data used in this study include primary and secondary data. Primary data is obtained or collected by researchers from the main source; from the research source or object through the results of interviews with respondents. Research sampling is conducted using probability sampling specifically proportionate stratified random sampling. Respondents in this research are PTPN V Riau employees who were recruited from 2011-2017. The number of research respondents are 90 employees. Furthermore, structured interviews are also conducted using questionnaires to experts as resource persons to determine strategies for improving employee performance.

\section{RESULTS AND DISCUSSION}

\section{General Description of the Respondents}

The general description of the respondents explains the characteristics of the respondents in this study. Research data were obtained from the questionnaires results that have been distributed to all respondents totaling 90 people with the characteristics of gender, age, working period, and last education. The following is an explanation of each respondent's characteristics.

\section{Gender}

Observation of gender identity was conducted through a questionnaire which found that the majority of leadership employees were men as many as 81 people or 90 percent and 9 female employees or 10 percent. PTPN $\mathrm{V}$ is a plantation company requiring more male worker than women because a lot of work is mostly done in the field and in factories.

Age

The age characteristic of respondents in Figure 10, show that respondents aged between 20-30 years were 23 people or 25.56 percent, respondents aged 31-40 
years were 33 people or 33.67 percent, respondents aged 41-50 years were 26 people or 28.89 percent, and respondents aged over 50 years old were 8 people or 8.89 percent. Based on the characteristics of the respondents' age, the majority of the respondent were in the age group of 31-40 years. It shows that the current leadership of PTPN V employees is in the productive age category so that it is easier for these individuals to improve their performance.

\section{Last education}

The characteristics of respondents were also based on last education. The level of education influences competency, ways of thinking, perspective on a problem and performance. The level of education in this study is divided into five groups consisting of high school/equivalent, associate's degree, bachelor's degree, master's degree, and doctoral degree. Based on the last education characteristics, most of the respondents had a bachelor's degree of 66 people or 73.33 percent. This is because in the recruitment and selection of leader employees, the candidate must possess at least bachelor's degree. The level of education of high school/equivalent consisted of 17 people or 18.89 percent. Associate's degree consisted of 2 people or 2.22 percent. The employee candidates graduated from high school/equivalent and associate's degree are generally recruited from internal companies. In addition, master's degree consisted of 5 people or 5.56 percent.

\section{Working Period}

The highest number of respondents with a working period of $<5$ years was 24 people or 26.67 percent. That is because the majority of PTPN V employees who were recruited in 2013 and 2015 were young or fresh graduate individuals. Respondents with a working period of 5-10 years were 22 people or 24.44 percent, working period $11-15$ years, 16-20 years, 21-25 years and 26-30 years respectively as many as 11 people or 12.22 percent. Generally, employees whose working periods were 16-20 years, 21-25 years and 26-30 years were employees who were recruited from internal company to become leader employees.

\section{Results of SEM-PLS Analysis Test Evaluation of Measurement Model (Outer Model)}

The measurement model evaluation was carried out with the help of the Smart PLS 3 program. There are two types of testing on the measurement model; i.e. validity and reliability tests. Validity test has two stages which include convergent validity and discriminant validity. Convergent validity is checked by looking at the loading factor and AVE (Average Variance Extracted). The discriminant validity is checked by looking at the crossloading value. Reliability test is seen through the stages of the reliability of the extract by looking at the value of composite reliability and the value of Cronbach's alpha.

The results of the loading factor are used to measure convergent validity of the measurement model. The loading factor values $<0.4$ must be excluded from the model (Lai and Fan 2008 and Vinzi et al, 2010) because the measurement model will not meet the criteria of convergent validity. In this study, the indicator that must be excluded from the model because of its invalidity is the X2.2 indicator or reference (Figure 3). Further retesting is done after invalid indicators are removed from the model (Figure 4).

The value of loading factors on the indicators of each latent variable is no longer worth $<0.4$. The AVE value describes the size of the variance or the diversity of indicators that latent variables can have. According to Ghozali (2014), the value of the acceptable AVE is> 0.5. After the evaluation of the measurement model was carried out, the AVE value for all latent variables was $>0.5$. It means that more than $50 \%$ of the diversity of indicators can be explained by each of the latent variables. Through these two criteria, 
the loading factor and AVE values, the data has met the stages of convergent validity (Table 2 ).

Composite reliability and Cronbach's alpha have the same interpretation meaning that all variables have values $>0.7$. It shows that the data has high reliability, or in other words, the internal consistency of each latent variable is very satisfying; the data for all latent variables is reliable (Table 2).

\section{Evaluation of Structural Models (Inner Model)}

The objective of this evaluation is to determine the effect of the relationship between exogenous latent variables on their endogenous variables. The criteria in the measurement model evaluation stage are the coefficient of determination $\left(\mathrm{R}^{2}\right)$ (Table 3), predictive relevance (Q2) and Goodness of Fit Index (GoF/ GFI).

The results of $\mathrm{Q}^{2}$ are considered to be good if the value is $>0$ which indicates that the exogenous latent variable is good (appropriate) as an explanatory variable that is able to predict its endogenous variables (Mustafa and Wijaya, 2012 and Ghozali, 2014). In this study, measurement model is reflective in which the Q-square value is $>0$. So, that the exogenous latent variable is able to be a good explanatory variable to predict its endogenous variables (Table 4).

In addition to using $\mathrm{R}^{2}$ and $\mathrm{Q}^{2}$, the overall structural model validation uses Goodness of Fit (GoF). GoF index is a single measure to validate the combined performance of measurement models and structural models. GoF values are between 0 and 1 with interpretations of values: 0.1 (small GoF); 0.25 (moderate GoF) and 0.36 (large GoF). According to Tenenhaus (2004), GoF can be calculated through the following formula.

$G o F=\sqrt{\overline{A V E} \times \overline{R^{2}}}$

Description: $\overline{A V E}$ AVE is the average value of AVE latent variables and $\overline{R^{2}}$ is the average value of $R^{2}$.

$$
\begin{gathered}
G o F=\sqrt{\overline{A V E} \times \overline{R^{2}}} \\
=\sqrt{\frac{0.655+0.573+0.771+0.728}{4} \times \frac{0.305+0.365+0.735}{3}} \\
=0.565
\end{gathered}
$$

In this study, the GoF value was large, so the overall model was considered as fair. Overall, the values of $\mathrm{R}^{2}, \mathrm{Q}^{2}$ and GoF indicate that the structural model is fair.

\section{Hypothesis testing}

In the path coefficient, each correlation of latent variables is in accordance with the hypothesis of the research model. The feasibility of the evaluation of the measurement model can be seen through $p$-value and t-statistics. Abdillah and Jogiyanto (2009) state that the measure of the significance value for supporting the research hypotheses can use a comparison of t-table and t-statistics values. If the t-statistics value is more than 1.96 and the probability value ( $\mathrm{p}$-value) is less than 0.05 or $5 \%$, then the research hypothesis is accepted.

\section{The Effect of Recruitment on Employee} Performance

Recruitment does not affect employee performance because the p-value and t-statistics do not meet the requirements; $p$-value $<0.05$ and t-statistic value $>1.96$ (Table 5). The results of the analysis show that recruitment has no effect on performance. This means that the recruitment process carried out has no effect on employee performance. Therefore, the better the recruitment the impact can be seen from the employee performance. The research findings confirmed the findings of previous studies conducted by Yullyanti (2009), Atikawati and Udjang (2016) which proved that recruitment does not have a positive effect on employee performance. According to Yullyanti (2009), in such (study, there is a strong assumption that the correlational path between recruitment and performance does not work directly but indirectly. 


\section{The Effect of Selection on Employee Performance}

Selection has a significant effect on employee performance because the value of t-statistics $>1.95$ or $p$-value $<0.05$ (Table 5). These results indicate that the selection process has a significant positive effect on employee performance. The point is that the selection process that has been implemented has an effect on employee performance. These research findings are supported by research conducted by Kanu (2015), Ghozi and Darwanto (2017), and Tarjiwo (2018), which prove that selection has a positive and significant effect on performance. The better the selection process, the better the performance and qualifications of the employees according to the needs of the organization. It will give output in the form of highperformance employee. It is supported by Mathis and Jackson (2006) who stated that selection activities focus on the knowledge, skills, and abilities of applicants. The absence of a good match between knowledge, skills, and abilities and job demands leads to low employee performance as well as increasing problems in other human resources.

\section{The Effect of Placement on Employee Performance}

Placement has a significant effect on employee performance (Table 5).. Positive value (7.294) indicates that employee performance in the company can be improved through appropriate employee placement. In PTPN V, the implementation of employee placement is in accordance with work knowledge, work skills, work experience and training that the employees have followed; so, the work can be carried out and mastered well. These research findings are supported by Sarinah et al (2016), Pratama et al (2017), and Runtuwene et al (2016). Placement can affect employee performance because good and appropriate placement will make employees have enthusiasm in work. That's because what they are doing is what they are interested in and the work is something they are well-versed in. This is supported by the opinion of Suwatno (2003) who stated that the employee placement aims to place employees according to their jobs and position that are in accordance with their abilities, skills and expertise.

\section{Effect of Recruitment on Employee Selection}

Recruitment has a significant effect on selection (Table 5). A positive value $(8,772)$ shows that there is a correlation between the recruitment process and selection of HR management functions. These research findings are also supported by previous research conducted by Yullyanti (2009) who stated that there is an effect of recruitment on selection. This proof corroborates the opinion of Ivancevich (2001) who mentioned that recruitment correlates directly with selection. So, this research model can maintain the path between recruitment and selection.

\section{Effect of Selection on Employee Placement}

Selection has a significant effect on placement. The analysis results show that the effect of selection on placements has the highest value of 11.387 (Table 5). That positive value indicates that the implementation of proper placement can be improved through a selection process. Appropriate employee placement based on the results of the selection should be based on the company's desires and employee's desires so that they know the scope of their work. They will work optimally to achieve company goals. These research findings are supported by previous research conducted by Dewi and Darma (2017) and Rajaguguk (2014) who found the effect of selection on job placement. This is reinforced by the opinion of Hasibuan (2010) who stated that employee placement is a follow-up of selection; i.e. placing prospective employees who have passed the selection in a vacant position and giving authority to that person. Thus, 
the employees can work on their duties in the related position.

\section{The Results of AHP Analysis Test}

In the preparation of the AHP, the questionnaires were distributed to several respondents who were considered as experts. Based on the results of data processing using Software Expert Choice 11, the hierarchical structure of the research along with its weight can be seen in Figure 5.

Actors are people who are involved and play a role in improving employee performance at PT Perkebunan Nusantara V Riau. Actors who play a role in PTPN V include: General Manager, Manager, Assistant Chief and Assistant. Based on the results of the data input presented above, it was concluded that the most dominant actors who have a large role to achieve the goals in improving the performance of employees of PTPN V are assistants with a weight of 0.415 or $41.5 \%$. Followed by assistant chief with a weigh of 0.282 or $28.2 \%$. In the third place is manager with a weight of 0.225 or $22.5 \%$, and the last actor is general manager with a weight of $0.077 \%$ or $7.7 \%$.

After discussing the actors who play a role in improving performance, then it discusses factors affecting the performance of employees of PTPN V. Furthermore, according to Table 6, the recruitment factor, which has a weight of 0.282 , is the highest priority in PTPN V.

Furthermore, the second sequence is the selection factor with a weight of 0.226 . The selection and recruitment factors do not differ in weight. Recruitment is essentially the process of determining and attracting applicants who are able to work in a company. The relation with selection is as an activity in HR management which is carried out after the recruitment process. The selection process is a means to decide whether prospective employees will be chosen or accepted. The better the recruitment and selection process, the better the performance. This finding is reinforced by the research conducted by Saddam and Mansor (2015) who found that effective recruitment and selection practices in companies_related to performance-will increase labor productivity, product quality, organizational innovation. Study conducted by Ekwoaba et al (2015) also stated that recruitment and selection can improve employee performance. The next factor that affects the performance of employees of PTPN V is placement with a weight of 0.176 , education and training 0.171 , and organizational culture 0.144 .

Furthermore, the goal of improving employee performance is to increase the productivity of plants and factory, improve business profitability, increase the competitiveness of companies in the related industry, and increase effectiveness and cost efficiency. Based on Table 7, the most influential goal in the process of improving employee performance is to increase the productivity of plants and factory with a weigh of 0.322 . The aim of increasing plant and factory productivity is the most dominant of the other objectives. Increasing productivity of plants and factory will increase company profits.

The next objective of improving performance is the effectiveness and cost efficiency with a weight of 0.274. Increased costs, due to cost, plant costs, increase in tariffs, wages and prices, require cost effectiveness and efficiency. Production costs are important factors that influence the high and low selling prices of the products produced. Therefore, it is important for companies to control production costs more effectively in their operational activities so that they can run it well and efficiently (Edison and Sapta, 2010). This is also in accordance with the research of Hapsari et al (2013) who found that control over production costs was effective against the efficiency of production costs. It means that the production costs incurred by the company 
are efficient. The next objective of improving performance is to increase business profitability $(0.218)$ and improve the competitiveness of companies in the industry (0.184).

The alternative strategy in improving the performance of PTPN V employees is to improve employee welfare, improve performance monitoring and evaluation, build performance and competency-based HR Management, and improve the recruitment system as needed.
Based on Table 8 , the results of the assessment of the experts through the synthesis of the weight assessment show that the most important alternative strategy in improving the performance of PTPN V employees is to improve the welfare of employees with a weight of 0.348 . Furthermore, it is followed by the development of performance and competency-based HR Management, improving the recruitment system according to needs and improving performance monitoring and evaluation.

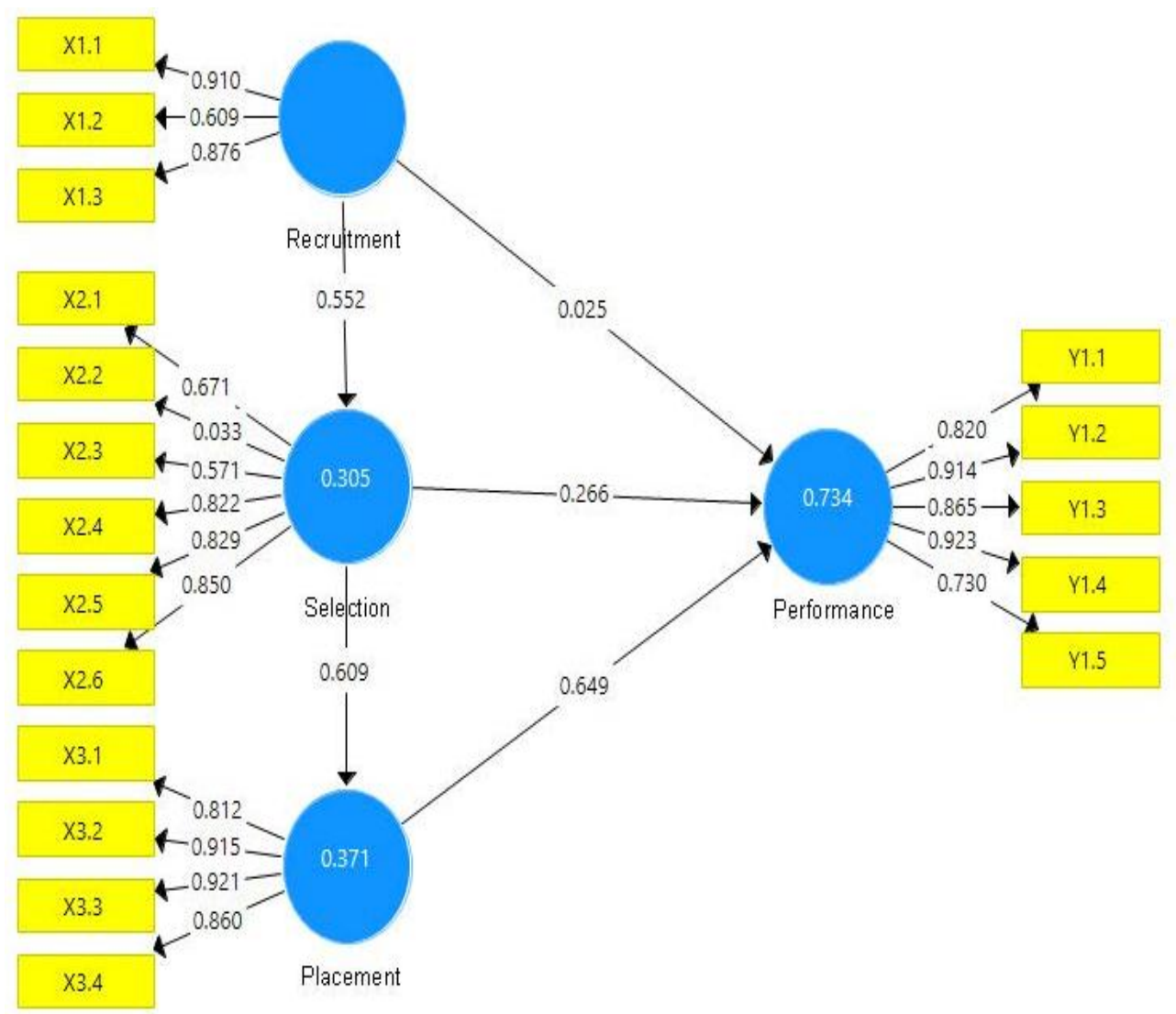

Figure 3. The initial model results from SEM PLS analysis 


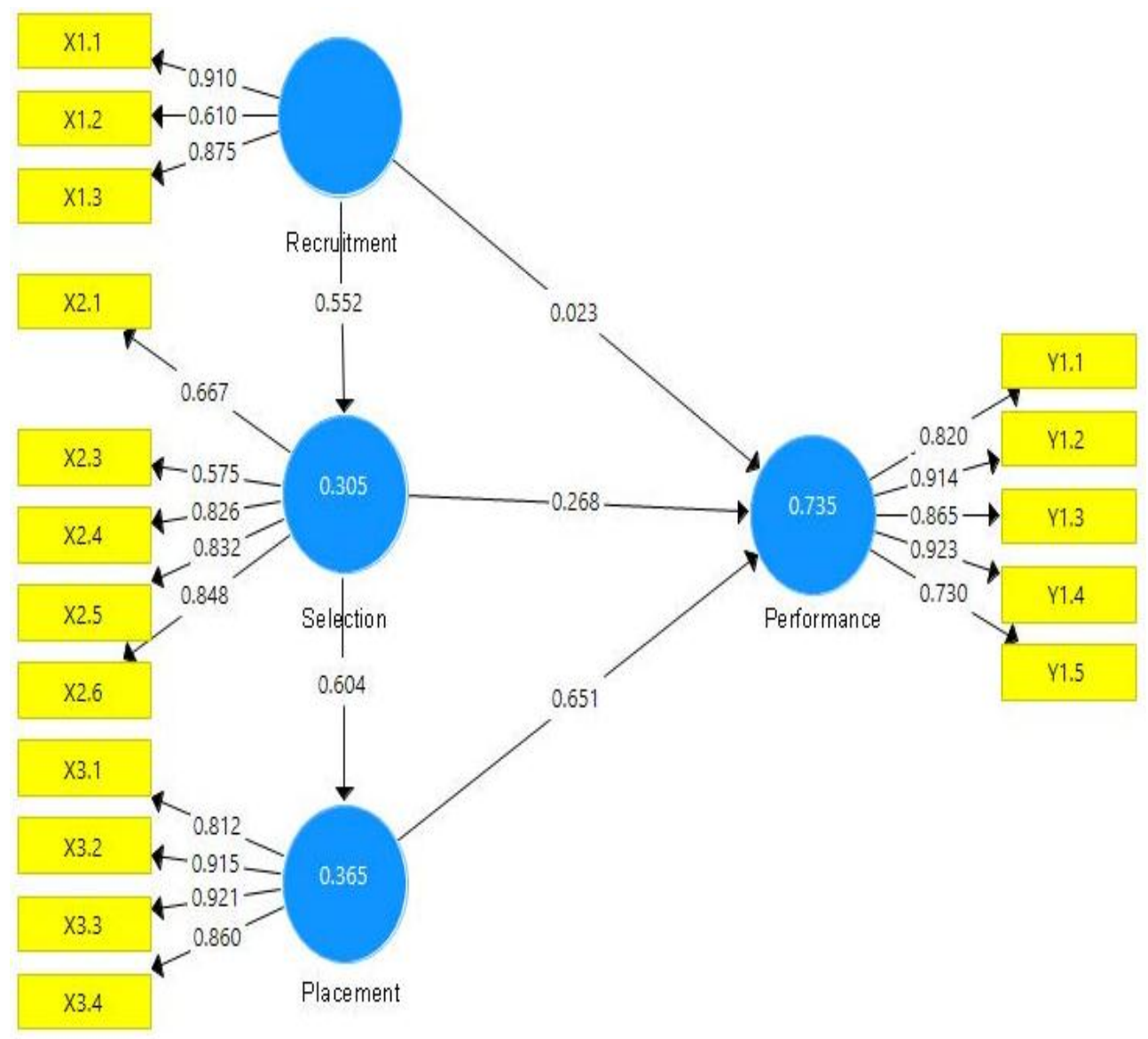

Figure 4. The model after indicator X2.2 is issued

Table 2. The value of Cronbach's Alpha, Composite Realibiliti and AVE

\begin{tabular}{ccccc}
\hline & Recruitment & Selection & Placement & Performance \\
\hline Cronbach's Alpha & 0.725 & 0.808 & 0.900 & 0.906 \\
\hline Composite Reliability & 0.847 & 0.868 & 0.931 & 0.930 \\
\hline AVE & 0.655 & 0.573 & 0.771 & 0.728 \\
\hline
\end{tabular}

Table 3. R-square results and criteria

\begin{tabular}{ccc}
\hline & $R$-Square & Criteria \\
\hline Selection $(\mathrm{X} 2)$ & 0.305 & Good \\
\hline Placement $(\mathrm{X} 3)$ & 0.365 & Good \\
\hline Performance (Y1) & 0.735 & Very good \\
\hline
\end{tabular}

Table 4. $\mathrm{Q}^{2}$ calculation results

\begin{tabular}{cccc}
\hline & SSO & SSE & $\mathrm{Q}^{2}(=1-\mathrm{SSE} / \mathrm{SSO})$ \\
\hline Recruitment $(\mathrm{X} 1)$ & 270.00 & 270.000 & \\
\hline Selection $(\mathrm{X} 2)$ & 450.00 & 378.626 & 0.159 \\
\hline Placement (X3) & 360.000 & 265.709 & 0.262 \\
\hline Performance (Y1) & 450.000 & 232.107 & 0.484
\end{tabular}


Tabel 5. Structural Model Path Coefficient

\begin{tabular}{ccccc}
\hline & $\begin{array}{c}\text { Original } \\
\text { sample } \\
(\mathrm{O})\end{array}$ & $\begin{array}{c}\text { Standard } \\
\text { Deviation } \\
(\text { STDEV })\end{array}$ & $\begin{array}{c}\text { T-Statistics } \\
(\mid \mathrm{O} / \text { STDEV } \mid)\end{array}$ & P-Values \\
\hline Recruitment->Selection & 0.552 & 0.063 & 8.772 & 0.000 \\
\hline Recruitment->Performance & 0.023 & 0.094 & 0.246 & 0.806 \\
\hline Selection->Placement & 0.604 & 0.053 & 11.387 & 0.000 \\
\hline Selection->Performance & 0.268 & 0.053 & 5.029 & 0.000 \\
\hline Placement->Performance & 0.651 & 0.089 & 7.294 & 0.000
\end{tabular}

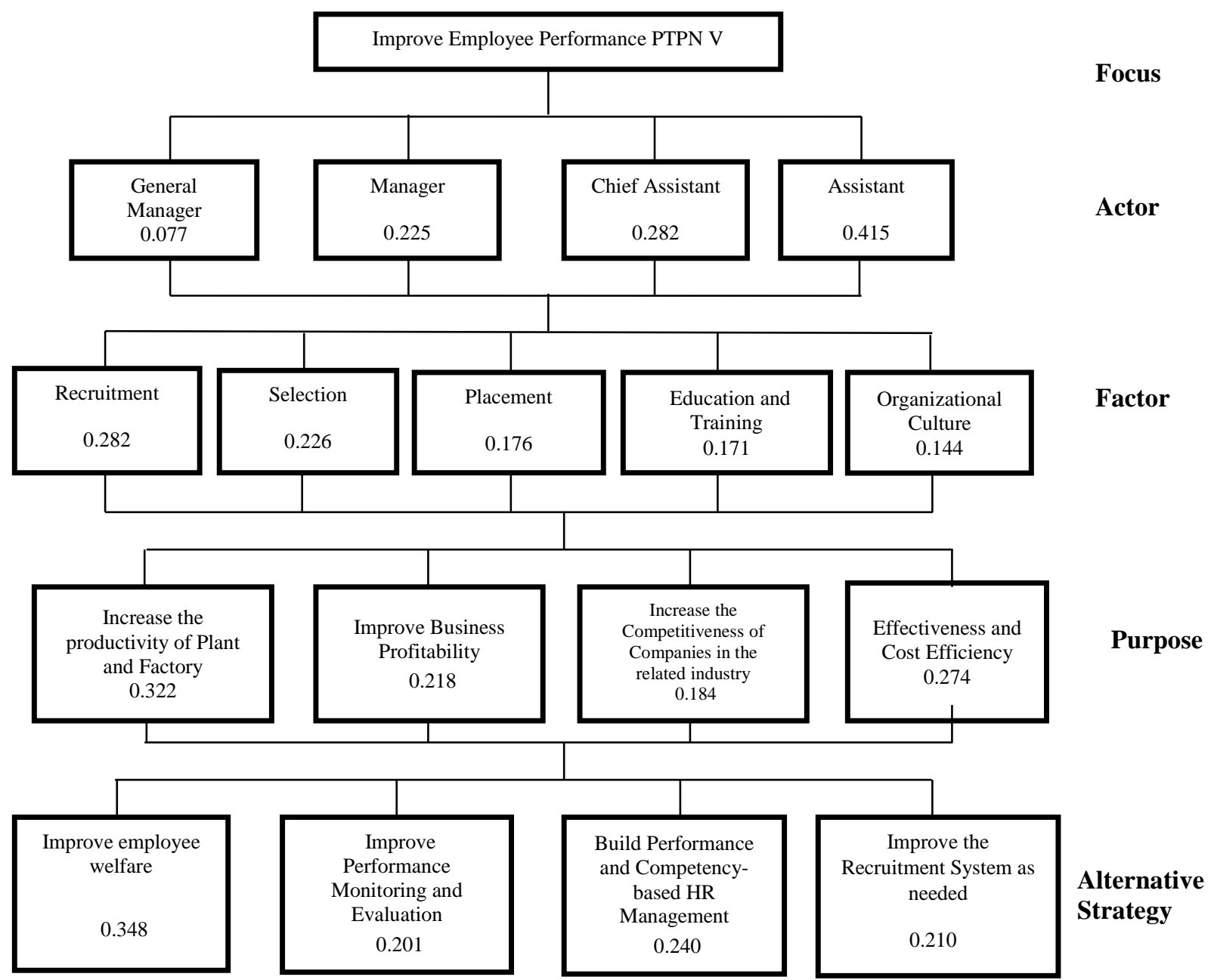

Source : Primary data is processed, 2018

Figure 5. Hierarchy Structure and Priority Weights of Each Element

Table 6. Priority Factor

\begin{tabular}{lccc}
\hline \multicolumn{1}{c}{ Factor } & Load & Percentage $(\%)$ & Priority \\
\hline Recruitment & 0.282 & 28.2 & 1 \\
Selection & 0.226 & 22.6 & 2 \\
Placement & 0.176 & 17.6 & 3 \\
Education and Training & 0.171 & 17.1 & 4 \\
Organizational Culture & 0.144 & 14.4 & 5 \\
\hline
\end{tabular}


Table 7. Purpose Priority

\begin{tabular}{lcccc}
\hline \multicolumn{1}{c}{ Purpose } & Load & Percentage (\%) & Priority \\
\hline $\begin{array}{l}\text { Increase the Productivity of Plant and } \\
\text { Factory }\end{array}$ & 0.322 & 32.2 & 1 \\
$\begin{array}{l}\text { Improve Business Profitability } \\
\text { Increase the Competitiveness of }\end{array}$ & 0.184 & 18.4 & 3 \\
$\begin{array}{l}\text { Companies in the related industry } \\
\text { Effectiveness and Cost Efficiency }\end{array}$ & 0.274 & 27.4 & 2 \\
\hline
\end{tabular}

Table 8. Alternative Strategy Priorities

\begin{tabular}{|c|c|c|c|}
\hline Alternative Strategy & Load & Percentage $(\%)$ & Priority \\
\hline Improve employee welfare & 0.348 & 34.8 & 1 \\
\hline $\begin{array}{l}\text { Improve Performance Monitoring and } \\
\text { Evaluation }\end{array}$ & 0.201 & 20.1 & 4 \\
\hline $\begin{array}{l}\text { Build Performance and Competency- } \\
\text { based HR Management }\end{array}$ & 0.240 & 24.0 & 2 \\
\hline $\begin{array}{l}\text { Improve the Recruitment System as } \\
\text { needed }\end{array}$ & 0.210 & 21.0 & 3 \\
\hline
\end{tabular}

\section{CONCLUSION AND SUGGESTION}

\section{Conclusion}

Research findings indicate that recruitment has a significant effect on selection, but does not have a significant effect on performance. Selection has a significant effect on performance, placement has a significant effect on performance and selection has a significant effect on placement. In the strategy to improve the performance of PTPN V employees, an alternative strategy that can be carried out is to improve employee welfare, development of performance and competency-based HR Management, improve the recruitment system according to needs, and improve performance monitoring and evaluation.

\section{Suggestion}

The company needs to conduct a proper job position analysis before conducting a series of HR selection and placement processes. Company must prepare a performance-based system to improve employee welfare. Company needs to improve human resources by carrying out training and education for leader employees. Further research, can raise the issue of job satisfaction, education and training, organizational culture and leadership style at PTPN V.

\section{REFERENCES}

Abdillah W, \& Jogiyanto H.M. (2009). Konsep dan Aplikasi PLS (Partial Least Square) Untuk Penelitian Empiris.Yogyakarta: Badan Penerbit Fakultas Ekonomi.

Adebola, B. Y. (2017). Recruitment and Selection Procedures and Their Relative Effectiveness on Employees Performance in the Hospitality Industri in Ogun State. International Journal of The Guild Contemporary Academic Researchers. 2(2) : 55-56.

Atikawati E., \& Udjang, R. (2016). Strategi rekrutmen dan Seleksi terhadap Kinerja Karyawan. Jurnal Perilaku dan Strategi Bisnis. 4(1): 923.

Aziz, T. A. (2017) Pengaruh Rekrutmen dan Seleksi terhadap Kinerja. Jurnal Aplikasi Bisnis dan Manajemen. 3(2): 246-253. 
Azzam A., \& Jaradat, S. (2014). Impact of HR Recruitment Process on Jordania Universities Effectiveness. European Centre for Reseach Training and Development. 2 (1) : 16-29.

Dewi, A. I. S., \& Darma, G. S. (2017). Proses Rekrutmen, Seleksi, Pelatihan, Penempatan dan Kinerja Karyawan. Jurnal Manajemen dan Bisnis. 14(1): 1-18.

Edison, E., \& Sapta, U. (2010). Pengaruh Biaya Standar terhadap Pengendalian Biaya Produksi studi kasus pada PT ITP, Tbk. Jurnal Ranggagading. 10(2): 121-130.

Ekwoaba, J. O., Ikeije, U. U., \& Ufoma, N. (2015). The Impact of Recruitment and Selection Criteria on Organizational Performance. Global Journal of Human Resource Management. 3(2): 22-33.

Gamage, A, S. (2014). Recruitment and Selection Pratices in Manufacturing SMEs in Japan : An analysis of the link with business performance. Ruhuna Journal og Management and Finance. 1(1) : 37-52.

Ghozali, I. (2014) Structural Equation Modelling (SEM) Metode Alternative dengan Partial Least Square. Semarang: Badan penerbit Universitas Diponegoro.

Ghozi, A., \& Darwanto. (2017). Pengaruh Seleksi dan Pelatihan terhadap Persepsi Kinerja Pegawai, dengan Kompetensi sebagai Variabel Intervening (Studi empirik pada Inspektorat Jenderal Kementerian Agama). Jurnal Ekonomi dan Bisnis. 7(1): 41-55.

Hapsari S. D,, Saputra, B. W., \& Rismadi, B. (2013). Evaluasi efektivitas pengendalian biaya produksi dan efisiensi biaya produksi (Studi kasus di PT.XYZ). Journal of Management Studies. 2(1): 38-60.
Ivancevich, M. (2001) Human Resource Management, New York: Mc. Grow - Hill Companies.

Kanu, A. M. (2015). How Do Recruitment and Selection Practices Impact Small and Medium Enterprises Performance in the Construction Industry in Sierra Leone? Journal of Economic and Sustainable Development. 6(5) : 253-269.

Kepha, O., Mukulu, E. \& Waititu, G. A. (2014). The Influence of Recruitment and Selection on the Performance of Employees in Research Institutes in Kenya. International Journal of Science and Research. 3(5): 132-138.

Kristanu, O. Y. (2013). Analisis Rekrutmen, Seleksi dan Penempatan Karyawan di PT. Nyonya Meneer Semarang. Jurnal Mahasiswa Manajemen Bisnis. 1(3): 1567-1571.

Lai, M. C., \& Fan, S. L. (2008). Use of Fit Perception in Employee Behavioral Criteria in Taiwan IT Industry. Business and Information. 5(1).

Mangkunegara, A. A. A. P. (2011) Manajemen Sumber Daya Manusia Perusahaan. Bandung: Rosdakarya Offset.

Mathis, R. L., \& Jackson, J. H. (2006) Manajemen Sumber Daya Manusia.Ed ke-10. Jakarta: Salemba Empat.

Mustafa, Z., \& Wijaya, T. (2012). Panduan Teknik Statistik SEM \& PLS dengan SPSS AMOS. Yogyakarta: Cahaya Atma Pustaka

Noe, R. A., Hollenbeck , J. R., Gerhart, B., \& Wright, P. M. (2010) Manajemen Sumber Daya Manusia Mencapai Keunggulan Bersaing. Buku 1 Edisi 6. Jakarta: Salemba Empat. 
Nuryanta, N. (2008). Pengelolaan Sumber Daya Manusia (Tinjauan Aspek Rekrutmen dan Seleksi). Jurnal Pendidikan Islam el-Tarbawi. 1(1): 55-69.

Palaniappan, N., \& Arasu, B. S. (2017). Impact of Effective Recruitment in Business Organization: A Brief Literatur Review. Imperial Journal of Interdisciplinary Research. 3(4): 1772-1774.

Pratama, A. R., Qomari, N., \& Negoro, B. K. (2017). Pengaruh Rekrutmen, Penempatan, Pelatihan terhadap Kinerja Karyawan pada PT. Unilever Indonesia, Tbk. Jurnal Manajemen Branchmark. 3(3) : 489-505.

PT Perkebunan Nusantara V. (2016) Laporan Tahunan 2016. Pekanbaru. PT Perkebunan Nusantara V.

Rajagukguk, F, L. (2014). Pengaruh Seleksi Kerja Pegawai terhadap Penempatan Kerja Pegawai pada Kantor Camat Muara Kabupaten Tapanuli Utara. Jurnal Eco UNITA. 2(1): 77-91.

Robbins, S. P. (2006) Perilaku Organisasi, Jakarta: PT Indeks, Kelompok Gramedia.

Runtuwene, P., Tewal, B., \& Mintardjo, C. (2016). Pengaruh Penempatan Kerja, Mutasi dan Beban Kerja terhadap Kinerja Karyawan pada PT. Bank Sulutgo Manado. Jurnal Berkala Ilmiah Efisiensi. 16(1): 269 - 279.

Saddam, A. K., \& Mansor, N. N. (2015). The role of recruitment and selection practices in the organizational performance of Iraqi Oil and Gas Sector : A brief literture review. Review of European Studies. 7(11): 348-358.

Sangeetha, K. (2010). Effective Recruitment : A Framework. The UIP Journal of Business Strategy. 7 (1) : 93-107.
Sarinah, G. R. S., \& Thabah, A. A. (2016). The Effect of Recruitment and Employee Selection on Employee Placement and Its Impacts Towards Employee Performance at PT Sriwijaya Air. Jurnal Manajemen Transportasi dan Logistik. 3(1) : 110.

Siagian, S. P. (2003) Teori \& Praktek Kepemimpinan. Jakarta: Rineka Cipta.

Simamora, H. (2004). Manajemen Sumber Daya Manusia, Edisi Ketiga, Yogyakarta: STIE YPKN.

Sinha, V., \& Thaly, P. (2013). A Review on Changing Trend of Recruitment Practice to Enhance the Quality of Hiring in Global Organizations. Management. 18 (2): 141-156.

Suwatno. (2003) Manajemen Sumber Daya Manusia. Jakarta: Erlangga.

Tanenhaus, D. S. (2004). Juvenile Justice in the Making. New York (US): Oxford University Press,

Tarwijo. (2018). Pengaruh Rekrutmen, Seleksi, dan Motivasi terhadap Kinerja Karyawan pada Toko Buku Gramedia Cinere. Jurnal Ilmiah Manajemen Forkamma. 1(4): 85 - 97

Vinzi, V., Esposito, Chin, W. W., Henseler, J., \& Wang, H. (2010) Handbook of Partial Least Squares : Concepts, Methods and Application. Springer Handbooks of Computational Statistics.

Yamin, S., \& Kurniawan, H. (2011). Partial Least Square Path Modeling. Jakarta: Salemba Infotek

Yullyanti, E. (2009). Analisis Proses Rekrutmen dan Seleksi pada Kinerja Pegawai. Jurnal Ilmu Admistrasi dan Organisasi. 16(3) : 131-139. 